\title{
BASICS OF THE CORRECTIVE - RESONANT SPECTRAL METHOD OF GAS FLOW IDENTIFICATION FROM THE DAMAGED PIPELINE AND ITS EXPERIMENTAL VERIFICATION \\ WYZNACZENIE PODSTAWY KOREKCYJNO - REZONANSOWEJ METODY WIDMOWEJ IDENTYFIKACJI WYPLYWU GAZU Z USZKODZONEGO GAZOCIĄGU I JEJ EKPERYMENTALNA WERYFIKACJA
}

\author{
Rafał Grądzki $^{1}$, Karol Golak ${ }^{1}$, Pawel Lindstedt ${ }^{2}$ \\ ${ }^{1}$ Politechnika Białostocka, Wydział Mechaniczny \\ ${ }^{1}$ Bialystok Technical University, Department of Mechanical Engineering \\ ${ }^{2}$ Air Force Institute of Technology, Instytut Techniczny Wojsk Lotniczych
}

\begin{abstract}
An important problem in the operation of gas pipelines is the identification of accidental gas leakage from the damaged pipeline. It is the hardest when the leakage is small. A disadvantage of prior methods is that with their use is only possible to identify and locate significant outflow with only a low accuracy. In proposed method of identifying the gas flow will be used a new signal from the corrective element " $r$ " attached to the tested pipeline and calculated from it and mass flow rate signals auto and cross power spectral density $S_{x x}, S_{y y}, S_{r r}, S_{x y}$, $S_{x r}, S_{y r}$. Using the power spectral density signals allows for transition from the signal diagnostic to the parameter diagnostic which is more effective. Assumptions methods will be verified at the experimental station.
\end{abstract}

Keywords: diagnostics, corrective element, weak interactions, amplitude gain, phase shift

Streszczenie: Ważnym problemem $w$ procesie eksploatacji gazociagów jest identyfikacja przypadkowego wyptywu gazu z uszkodzonego gazociagu. Największa trudność sprawia lokalizacja i identyfikacja wycieku, gdy jest on maty. Wada dotychczasowych metod jest to, ize przy ich uzyciu możliwe jest jedynie identyfikowanie znacznych wyplywów i lokalizowanie ich tylko ze zgrubna dokładnościa. W zaproponowanej metodzie identyfikacji wyptywu gazu zostanie wykorzystany nowy sygnał z korektora $r$ dołaczonego do badanego gazociagu oraz gesstości widmowe mocy sygnałów własne $S_{x x}, S_{y y}, S_{r r} i$ wzajemne $S_{x y}, S_{x r}, S_{y r}$ (gdzie $y$ to sygnat $z$ dowolnego czujnika ciśnienia lub masowego natężenia przepływu). Wykorzystanie do analizy mocy sygnatów pozwoli na przejście od diagnostyki sygnatowej do diagnostyki parametrycznej, która jest skuteczniejsza. Założenia metody zostana zweryfikowane na stanowisku eksperymentalnym.

Stowa kluczowe: diagnostyka, korektor, stabe interakcje, wzmocnienie amplitudowe, przesunięcie fazowe 
Basics of the corrective - resonant spectral method of gas flow identification... Wyznaczenie podstawy korekcyjno - rezonansowej metody widmowej identyfikacji..

\section{BASICS OF THE CORRECTIVE - RESONANT SPECTRAL METHOD OF GAS FLOW IDENTIFICATION FROM THE DAMAGED PIPELINE AND ITS EXPERIMENTAL VERIFICATION}

\section{Introduction}

The process of diagnosing long pipelines is a difficult process due to its big size and complicated construction. The biggest problem is location and identification of outflow - especially if the leak is small. Obtained results are usually not sufficiently precise. This is due to the poor diagnostic capability of the gas pipeline, resulting in a lack of diagnostic information, inter alia, from the large size and complex dynamics of the pumping process. The whole process of long gas pipelines leak detection can be divided into 4 stages $[4,15,16]$ :

- detection of the outflow,

- location of the outflow,

- whether the outflow is intentional or is a result of leak,

- estimate of the outflow.

This process can take place through a number of different methods, each with its own limitations, the most common types of leak detection methods are:

- acoustic methods [5, 13], main drawbacks of this method is low usability for leaks witk small mass flow, numerous false alarms

- direct observation: eg thermal imaging (carried out with helicopters, satellites) by using portable gas concentration sensors and trained dogs. The main disadvantage of these methods is the lack of constant observation [12, 13]

- monitoring of flows and pressures: false alarms, no possibility of accurate location $[11,13]$

- computer modeling, neural networks, Kalman filter, etc. The drawbacks are the need to have a very accurate mathematical model of the pipeline or a large database and occured false alarms $[1,15]$

Methods described above are mainly methods based on signals analysis, each of which has both its strengths and weaknesses. Common practice is therefore the use of several parallel leakage detection methods, resulting in significant cost increases. So, there is the need to develop a method of leak detection in long pipelines that do not require significant redevelopment. In this article, the authors want to show the basics of the transition from signal diagnostics $[7,8,9]$ to more accurate parametric diagnostics $[3,6]$, using an additional diagnostic signal from the corrector element attached to the pipeline. 


\section{Test stand equipped with corrective elements}

Simplified component connection diagram with obtained signals are shown in fig. $1[2]$.

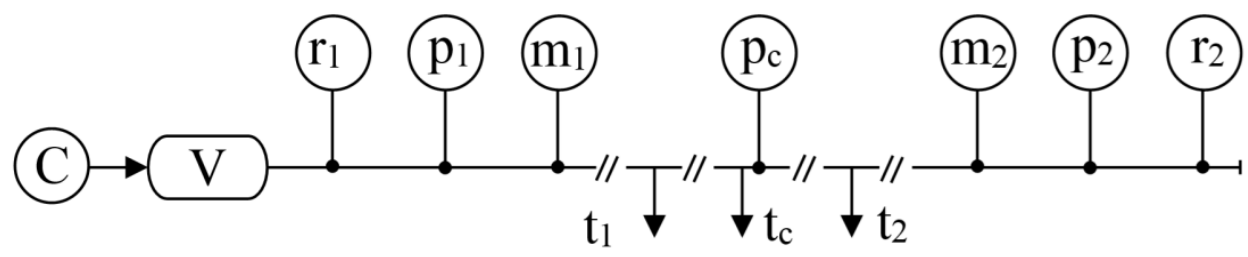

Fig. 1 Schematic diagram for studying the leakages from the long pipelines, where:

$C$-compressor, $V$ - pressure vessel, $r$-corrective element,

$p$-pressure sensor, $m$ - mass flow meter, $t$-faucets.

Test stand builded based on scheme from fig. 1. are shown in fig. 2 .

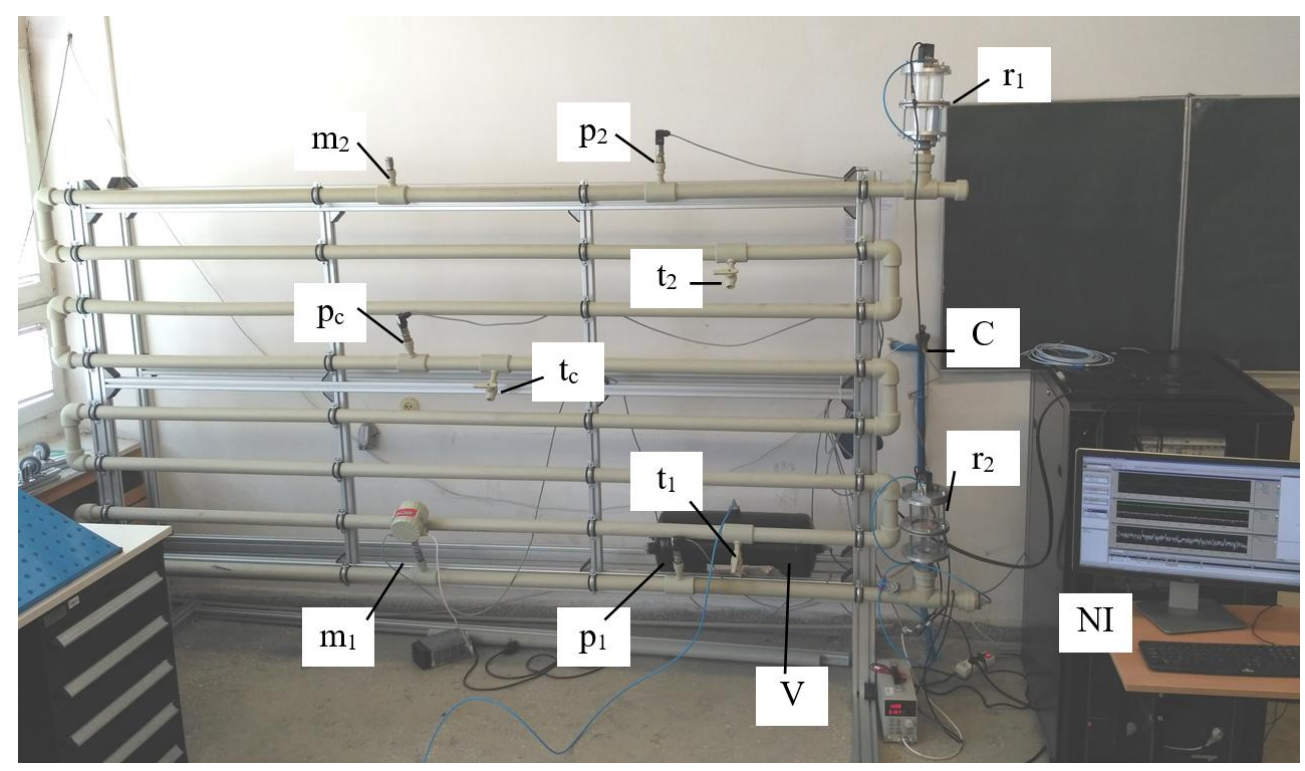

Fig. 2 Stand for leak detection from pipelines; where:

$C$ - connection to the compressor, $V$ - pressure vessel, $r_{1}, r_{2}$-corrective element, $p_{1}, p_{c}, p_{2}$ - pressure sensors, $m_{1}$ - mass flowmeter, $m_{2}$ - place for mounting second flow sensor, $t_{1}, t_{2}, t_{3}$-faucets, NI - measuring apparature.

The stand consists 27 meters welded together PPR pipes (internal Ф45). At the beginning and the end of teh pipeline, corrective element was installed. Correctors $\left(r_{1}\right.$ and $\left.r_{2}\right)$ were constructed from two chambers separated by a removable membrane in the form of a $0.5 \mathrm{~mm}$ thick copper plate. Membrane was fit so that at the time of the leak there was its oscillation (this is an additional diagnostic signal). 
Basics of the corrective - resonant spectral method of gas flow identification... Wyznaczenie podstawy korekcyjno - rezonansowej metody widmowej identyfikacji..

To measure the membrane oscilations, in top of one chamber a hole was cut and a glass was glued (it allows to observe the vibrations by the laser displacement sensor over it). The glass was selected to allow light to pass through the laser wavelength emitted by the sensor.

After the first corrective element were mounted the pressure sensor $\left(p_{I}\right)$, mass flow $\left(m_{l}\right)$ and first faucet $\left(t_{l}\right)$ (to simulate gas leakage simulation by air extractions). An additional pressure sensor $\left(p_{c}\right)$ and faucet $\left(t_{c}\right)$ were installed near the pipeline center. On the end of the pipeline are mounted faucet $\left(t_{2}\right)$, location for the second mass flow meter $\left(m_{2}\right)$ and pressure sensor $\left(p_{2}\right)$.

Air is delivered to the pipeline using compressor. The next component is a 25 liter gas tank acting as a buffer - so that there are no drops of air during the leak simulation.

The measuring equipment was connected to National Instruments apparature, which was used to record signals from used sensors.

\section{Signal analysis of the simulated leaks.}

The illustrations show examples of leakage simulation results from the faucet on the beginning of the pipeline $\left(t_{l}\right)$. Fig. 3a. shows the signal of pressure changes, fig. 3b. measured membrane oscillations in the corrector.

a)

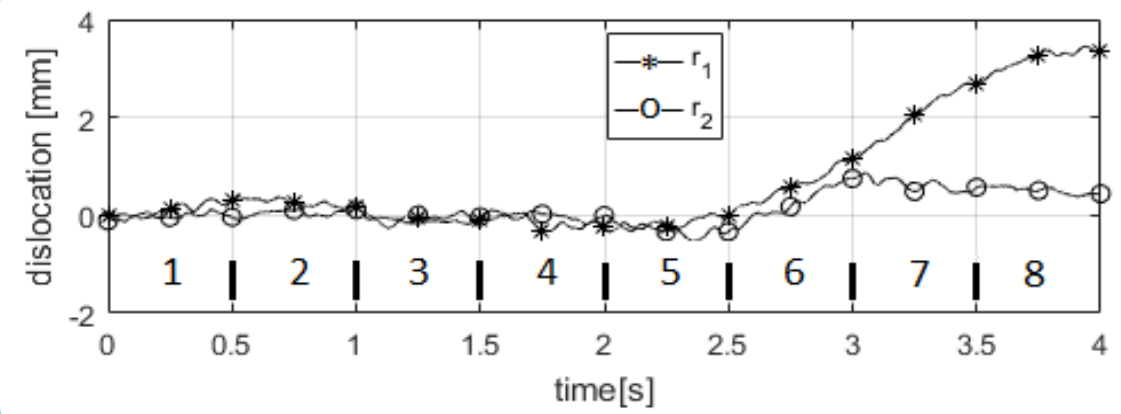

b)

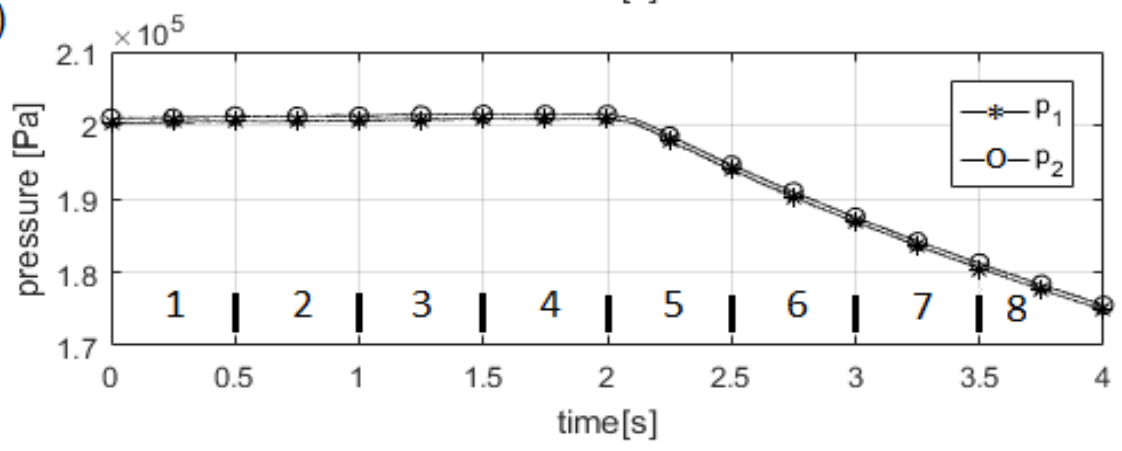

Fig. 3 a Membrane oscilation signals $r_{1} i r_{2}$,

Fig. $3 b$ pressure signals $p_{1} i p_{2}$ during the air outflow from faucet $t_{1}$ divided into test periods of time (1-8). 
From the graphs it is possible to read the location of the simulated leak, which occurred about $2 \mathrm{~s}$ (there was a pressure drop). In fig. $3 \mathrm{~b}$. signal of the membrane oscillation is shown. The reference point is 0 - the state in which the membrane is stationary (does not vibrate). After about 2.5 seconds you will notice the membrane movement. In the current configuration, changes in graphs can only be observed with larger spills. With very little leakage, the vibration of the equalizer membrane is practically unnoticeable. In order to increase sensitivity, diminishing circles will be extruded over the entire surface of the copper membrane. Rubber membranes of varying thicknesses were also tested, but too large membrane displacement caused it's permanent deformation, hence the decision to replace them. In the future, a rubber diaphragm option with a centered copper plate will also be tested. These treatments should, according to the authors, significantly increase the sensitivity of the correctors.

\section{Theoretical basics of a new method for diagnosing gas outflows from long gas pipelines}

In the proposed gas flow identification method can be used: $y$ - signal from selected sensor (pressure or mass flow), $x$ - environment signal and new signal from corrector $r$ (displacement of the membrane). Based on this three signals, many variants of its spectral power density could be determined (in the frequency domain $\omega): S_{x x}, S_{y y}, S_{r r}$ and $S_{x y}, S_{x r}, S_{y r}$. [10]

Use for signal power analysis allows you to switch from signal diagnostics to parametric diagnostics, which is more effective. The new method uses the possibility of transitioning from signals in time space $t$ and time space $\tau$ to signals in frequency domain $\omega$ resulting from signal processing theory $[3,6,14]$.

Thus, the relations between the $S_{y r}$ signals are expressed as amplitude gain $\left(A^{2}\right)$ and phase shift $(\varphi)$.

$$
\begin{gathered}
A^{2}=\frac{S_{y y}}{S_{x x}} \\
\varphi=\operatorname{Arg} \frac{S_{y x}}{S_{x x}}
\end{gathered}
$$

where:

$y$ - signal from selected sensor,

$x$ - environment signal

It can be assumed that the environment does not change if the period of observation of successive time periods (for the same or different signals) analyzed at the same time will be very short. 
Basics of the corrective - resonant spectral method of gas flow identification... Wyznaczenie podstawy korekcyjno - rezonansowej metody widmowej identyfikacji..

Then you can designate a new abstract interpretable physical quantity in the form of amplitude gains quotient:

$$
A_{y y}^{2}=\frac{\frac{S_{y y}^{T 12}}{S_{x x}^{T / 2}}}{\frac{S_{y y}^{T 01}}{S / x x}} \underset{S_{x x}^{T y 1} \cong S_{x x}^{T 01}}{\longrightarrow} \frac{S_{y y}^{T 12}}{S_{y y}^{T 01}} \text { (5) lub } A_{r y}^{2}=\frac{\frac{S_{r r}}{S / x x}}{\frac{S_{y y}}{S / x x}} \stackrel{S_{x x} \cong S_{x x}}{\longrightarrow} \frac{S_{r r}}{S_{y y}}
$$

where: $T^{01}, T^{12}$ - successive short periods of time.

A given model can also be written in the parameterized form:

$$
A^{2}=\frac{M_{0}+M_{1} s+M_{2} s^{2}+\ldots+M_{n} s^{n}}{L_{0}+L_{1} s+L_{2} s^{2}+\ldots+L_{n} s^{n}}
$$

In the proposed gas leakage identification method, an corrector signal $r_{I}$ (membrane displacement) and a $p_{1}$ signal from the pressure sensor will be used. Based on the two signals, the parameters of the $A^{2}$ model will be determined in two variants. In the first case, the signal $r_{l}$ (4 seconds) was divided into 8 smaller parts lasting $0.5 \mathrm{~s}$ (Fig 3a). That made it possible to assume that in short periods of time the environment would not change.

Calculations were performed by using the $r_{l}$ signal in the first model (pattern 8) with successive episodes of time. In the second case, the power spectral densities of two different signals $r_{l}$ and $p_{l}$ were used at the same time intervals in the same time period.

Diagnostic models $A^{2}$ will take the following form:

$$
\begin{aligned}
& A_{r 2 r 1}^{2}=\frac{S_{r 1 \_2}}{S_{r 1 \_}} \\
& A_{r 1 p 1}^{2}=\frac{S_{r 1 \_1}}{S_{p 1 \_1}}
\end{aligned}
$$

where $r_{I_{-} 2}$ - membrane oscillation in corrector $r_{l}$ in 2 test time periods (from 0.5 to $1 \mathrm{~s}$ ) according to Fig. 3a., etc.

In the tab. 1. parameters for model $A_{r l r l}^{2}$ are shown, for $A_{r l p l}^{2}$ in tab. 2. 
Tab. 1 Coefficients for the model $A_{r I r l}^{2}$ (Fig. $3 b$ ) for the signals from the first correctors $\left(r_{1}\right)$ at different time periods

\begin{tabular}{|c|c|c|c|c|c|c|c|c|c|c|c|c|}
\hline & $\mathbf{L}_{0}$ & $\mathbf{L}_{1}$ & $\mathbf{L}_{2}$ & $\mathbf{L}_{3}$ & $\mathbf{L}_{4}$ & $\mathbf{L}_{5}$ & $\mathbf{M}_{0}$ & $\mathbf{M}_{1}$ & $\mathbf{M}_{2}$ & $\mathbf{M}_{3}$ & $\mathbf{M}_{4}$ & $\mathbf{M}_{5}$ \\
\hline $\mathbf{A}_{r}^{2}$ & 0,84 & $-1,13$ & 0,07 & 0,50 & $-0,39$ & 0,17 & 0,94 & $-1,13$ & 0,05 & 0,50 & $-0,38$ & 0,17 \\
\hline $\mathrm{A}_{\mathrm{r} 3 \mathrm{r} 2}^{2}$ & 1,19 & -1.15 & $-0,02$ & 0,51 & $-0,37$ & 0,16 & 0,84 & $-1,13$ & 0,07 & 0,50 & $-0,39$ & 017 \\
\hline & $-0,03$ & $-0,95$ & 0,24 & 0,44 & $-0,41$ & 19 & 1,19 & $-1,15$ & $-0,02$ & 0,51 & $-0,37$ & 16 \\
\hline & 0,38 & $-1,05$ & 0,18 & 0,46 & $-0,41$ & 0,19 & $-0,03$ & $-0,95$ & 0,24 & 0,44 & $-0,41$ & 0,19 \\
\hline & 1,03 & $-1,15$ & 0,03 & 0,51 & $-0,38$ & 0,16 & 0,38 & $-1,05$ & 0,18 & 0,46 & $-0,41$ & 0,19 \\
\hline & 1,01 & $-1,15$ & 0,04 & 0,51 & $-0,38$ & 0,16 & 1,03 & $-1,15$ & 0,03 & 0,51 & $-0,38$ & 0,16 \\
\hline$A_{r 8 r 7}^{2}$ & 0,97 & $-1,15$ & 0,05 & 0,50 & $-0,38$ & 0,17 & 1,01 & $-1,15$ & 0,04 & 0,51 & $-0,38$ & 0,16 \\
\hline
\end{tabular}

Tab. 2 Coefficients for the model $A_{r 1 r l}^{2}$ (Fig. $3 a$ and $3 b$ ) for the signals from the first correctors $\left(r_{1}\right)$ and from first pressure sensor $\left(p_{1}\right)$ at different time periods

\begin{tabular}{|c|c|c|c|c|c|c|c|c|c|c|c|c|}
\hline & $\mathbf{L}_{0}$ & $\mathbf{L}_{1}$ & $\mathbf{L}_{2}$ & $\mathbf{L}_{\mathbf{3}}$ & $\mathbf{L}_{4}$ & $\mathbf{L}_{5}$ & $\mathbf{M}_{0}$ & $\mathbf{M}_{1}$ & $\mathbf{M}_{2}$ & $\mathbf{M}_{3}$ & $\mathbf{M}_{4}$ & $\mathbf{M}_{5}$ \\
\hline $\mathbf{A}_{\mathrm{r} 1 \mathrm{p} 1}^{2}$ & 0,94 & $-1,13$ & 0,05 & 0,50 & $-0,38$ & 0,17 & 0,85 & $-1,14$ & 0,08 & 0,50 & $-0,39$ & 0,17 \\
\hline & 0,84 & $-1,13$ & 0,07 & 0,50 & $-0,39$ & 0,17 & 0,85 & $-1,14$ & 0,08 & 0,50 & $-0,39$ & 0,17 \\
\hline & 1,19 & $-1,15$ & $-0,02$ & 0,51 & $-0,37$ & 0,16 & 0,85 & $-1,14$ & 0,08 & 0,50 & $-0,39$ & 0,17 \\
\hline & $-0,03$ & $-0,95$ & 0,24 & 0,44 & $-0,41$ & 0,19 & 0,85 & $-1,14$ & 0,08 & 0,50 & $-0,39$ &, 17 \\
\hline $\mathbf{A}_{r 5 p 5}^{2}$ & 0,38 & $-1,05$ & 0,18 & 0,46 & $-0,41$ & 0,19 & 0,85 & $-1,14$ & 0,08 & 0,50 & $-0,39$ & 0,17 \\
\hline$A_{r 6 p 6}^{2}$ & 1,03 & $-1,15$ & 0,03 & 0,51 & $-0,38$ & 0,16 & 0,85 & $-1,14$ & 0,08 & 0,50 & $-0,39$ & 0,17 \\
\hline & 1,01 & $-1,15$ & 0,04 & 0,51 & $-0,38$ & 0,16 & 0,85 & $-1,14$ & 0,08 & 0,50 & $-0,39$ & 0,17 \\
\hline $\mathbf{A}_{\mathrm{r} 8 \mathrm{p} 8}^{2}$ & 0,97 & $-1,15$ & 0,05 & 0,50 & $-0,38$ & 0,17 & 0,85 & $-1,14$ & 0,08 & 0,50 & $-0,39$ & 0,17 \\
\hline
\end{tabular}

Fig. 3 shows that the leak occurred after approximately $2 \mathrm{~s}$. Analysis of the changes of model $A_{r 4 r 3}^{2}(2.0-1.5 \mathrm{~s}$.$) and A_{r 5 r 4}^{2}(2.5 \mathrm{~s} \div 2 \mathrm{~s})$ parameters compared to parameters at other times (tab. 1) also shows that leakage. Significant change of parameters can be observed especially on $L_{0}$ and $M_{0}$.

For Tab. 2, there was also a change of parameters (especially for $L_{0}$ ) at the time of simulated leakage $A_{r 4 p 4}^{2}$ (about 2 seconds), $A_{r 5 p 5}^{2}$ (about 2.5 seconds).

In the next articles will be examined in what case will be changed also the other parameters and the model will be examined in the form of difference phase shifts. In the next articles we will analyze in what case will also be changes of other parameters and we will examine models in the different form of phase shifts.

The test results will also be verified after the modification of the current test stand in accordance with the notes described in Chapter 3.

\section{Summary}

The paper presents a stand for testing gas flow from long pipelines. The results of the measurements on simulated significant outflows were presented. The steps of subsequent modifications to increase the sensitivity of the mounted equalizers are described, and thus an increase in signal change in the event of even small leaks. The concept of a new diagnostic method based on the power spectra density (with the signals generated by the attached correctors) was also presented. 
Basics of the corrective - resonant spectral method of gas flow identification... Wyznaczenie podstawy korekcyjno - rezonansowej metody widmowej identyfikacji..

It should also be noted that the used correctors do not affect the static and dynamic quality of the studied pipelines.

In addition, the transition to time-frequency analysis of signals (using the parameterized $A^{2}$ and $\varphi$ models) gives far greater possibilities than the use of methods based on quality indicators, the number of which is limited.

\section{Literature}

[1] Abdulimen K. E., Susu A. A., Liquid pipeline leak detection system: model development and numerical simulation, Chemical Engineering Journal, Volume 97, Issue 1, 2004.

[2] Grądzki R, Golak K, Lindstedt P, Bartoszewicz B. Reasons for the experimental research of gas outflows based on the signals of weak interactions between the tested model of the gas pipeline, and tested equalizer. Journal of KONBiN 2015, nr 2(34) s.39-48.

[3] Grądzki R, Golak K, Lindstedt P. Parametric and nonparametric diagnostic models for blades in the rotating machinery with environment elimination. Journal of KONES Vol. 23, nr 2 (2016), s. 137-145

[4] Kowalczuk Z., Gunawickrama K.: Detekcja i lokalizacja wycieków w rurociągach przesyłowych. Rozdział 21 pracy zbiorowej pod red. J. Korbicza, J. Kościelnego, Z. Kowalczuka i W. Cholewy: Diagnostyka procesów. Modele metody sztucznej inteligencji, zastosowania. Warszawa, WNT, 2002.

[5] Kunze U., Experience with the acoustic leakage monitoring system, Prog Nucl Energy, 34 (3) (1999).

[6] Lindstedt P., Grądzki R., Model for blade diagnosis in a working rotor machine employing the method of virtual elimination of stochastic environment. Archive of Mechanical Engineering, Vol. 58, nr 3 (2011), s. 305-318.

[7] Lindstedt P., Słabe interakcje w procesie diagnozowania wycieków z układów hydraulicznych, Prace naukowe ITWL. Zeszyt nr 102000.

[8] Lindstedt P., The method of complex worthiness assessment of an engineering object in the process of its use and service, Solid State Phenomena, vol. 144/2009, Trans Tech Publications, Switzerland 2009.

[9] Lindstedt P., Weak interactions between objects in the signal-based and parametric diagnostics of transport-dedicated complex engineering systems, Aircraft Engineering and Aerospace Technology Vol.77, nr 3 (2005), s. 222-227.

[10] Lindstedt P.,Praktyczna diagnostyka maszyn i jej teoretyczne podstawy, Wydawnictwo Naukowe ASKON, Warszawa 2002.

[11] Liu, A. E., February 2008. Overview: Pipeline Accounting and Leak Detection by Mass Balance, Theory and Hardware Implementation.

[12] Scott, S. L., and Barrufet, M. A., 2003, "Worldwide Assessment of Industry Leak Detection Capabilities for Single \& Multiphase Pipelines," Project Report Prepared for the Minerals Management Service, OTRC Library Number: 8/03A120, University of Texas, Austin. 
[13] Sivathanu Y. Natural Gas Leak Detection in Pipelines. U.S. Department of Energy, National Energy Technology Laboratory, 2003

[14] Szabatin J., Podstawy teorii sygnałów, WKŁ Warszawa 2000.

[15] Tomasik P. Zastosowania modeli dokładnych sieci do detekcji i lokalizacji wycieków. In: Diagnostics of Processes and Systems; 2011. p. 507-512.

[16] Zhang J.: Statistical pipeline leak detection forall operating conditions. Pipeline \& Gas Journal, February 2001.

\section{Rafat Gradzki accomplished part of the above research within the $S / W M / 1 / 2016$ work financed from the resources for the Ministry of Science and Higher Education.}

Karol Golak accomplished part of the above research within the $S / W M / 2 / 2017$ work financed from the resources for the Ministry of Science and Higher Education.

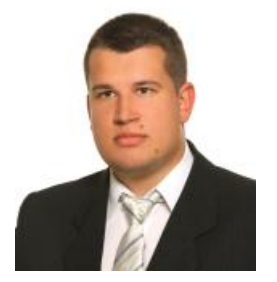

Rafal Gradzki PhD Eng. of the Faculty of Mechanical Engineering at the Bialystok University of Technology. Research subjects: technical diagnostics of bus engines, examination of potential reliability and safety, vibroacoustic diagnostics (Share 33\%).

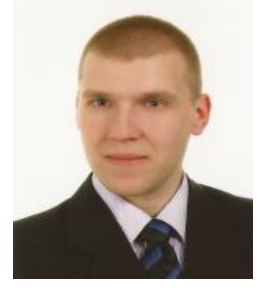

Karol Golak, PhD Eng. of the Faculty of Mechanical Engineering at the Bialystok University of Technology. Research subject: technical diagnostics of turbojet engine, reliability and control of mechanical objects (Share 33\%).

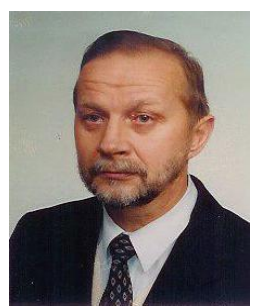

Prof. dr hab. inz Pawet Lindstedt, professor of the Air Force Technical Institute. Research subjects: Construction and utilisation of machines, applied automatics, diagnostics and reliability of machines. His works concern diagnostics of aircraft engines, hydraulic systems, and bearing systems with functional, vibroacoustic and wear methods (Share 33\%). 
Basics of the corrective - resonant spectral method of gas flow identification... Wyznaczenie podstawy korekcyjno - rezonansowej metody widmowej identyfikacji..

\section{WYZNACZENIE PODSTAWY KOREKCYJNO - REZONANSOWEJ METODY WIDMOWEJ IDENTYFIKACJI WYPLYWU GAZU Z USZKODZONEGO GAZOCIĄGU I JEJ EKPERYMENTALNA WERYFIKACJA}

\section{Wstęp}

Proces diagnozowania gazociągów przesyłowych jest procesem trudnym ze względu na rozmiary i skomplikowaną budowę gazociągu.

Największym problemem $\mathrm{w}$ diagnozowaniu jest lokalizacja oraz identyfikacja wypływu - zwłaszcza w przypadku gdy wyciek jest on mały. Otrzymywane wyniki są zazwyczaj nie wystarczająco precyzyjne. Jest to spowodowane małą podatnością diagnostyczną gazociągów powodującą niedobór informacji diagnostycznych (zmniejszenie skuteczności diagnozowania), wynikającą między innymi z dużych rozmiarów i złożonej dynamiki procesu tłoczenia.

Proces wykrywania wycieków gazu z długich rurociągów można podzielić na 4 etapy: $[4,15,16]$

- stwierdzenie (wykrycie) wypływu,

- lokalizacja wypływu,

- stwierdzenie czy wypływ jest celowy czy jest skutkiem nieszczelności,

- oszacowanie wypływu.

Proces ten może odbywać się za pomocą szeregu różnych metod z których każda ma swoje ograniczenia, najpopularniejsze typy metod wykrywania wycieków to:

- metody akustyczne [5,13], podstawowa wada to niska użyteczność małych wyciekach, liczne fałszywe alarmy

- obserwacje bezpośrednie: np. termowizyjne (przeprowadzane zarówno przy pomocy śmigłowców, satelit, przenośnych czujników stężenia gazu jak i za pomocą wytresowanych psów. Podstawową wadą tych metod jest brak możliwości stałej obserwacji $[12,13]$

- monitorowanie przepływów i ciśnień: fałszywe alarmy, brak możliwości dokładnej lokalizacji wypływu $[11,13]$

- modelowanie komputerowe, wykorzystanie sieci neuronowych, filtru Kalmana, itd. wady to konieczność posiadania bardzo dokładnego modelu matematycznego rurociągu albo dużej bazy danych oraz występujące fałszywe alarmy [1, 13]

Powyżej opisane metody są metodami sygnałowymi, a każda $\mathrm{z}$ nich ma zarówno swoje mocne i słabe strony. Często stosowaną praktyką jest $\mathrm{z}$ tego względu stosowanie równolegle kilku metod wykrywania wycieków równolegle co powoduje znaczący wzrost kosztów. Stad potrzeba opracowania metody umożliwiającej diagnozowanie wycieków w długich rurociągach nie wymagających ich znaczącej przebudowy.

$\mathrm{W}$ prezentowanym artykule autorzy chcą ukazać podstawy przejścia z diagnostyki sygnałowej $[7,8,9]$ do precyzyjniejszej, skuteczniejszej diagnostyki parametrycznej $[3,6]$ wykorzystując dodatkowy sygnał diagnostyczny z dołączonych do rurociągu korektorów. 


\section{Stanowisko badawcze wyposażone w korektory badawcze}

Uproszczony schemat podłączeń wraz $\mathrm{z}$ wykorzystywanymi sygnałami został przedstawiony na rys. 1. [2]

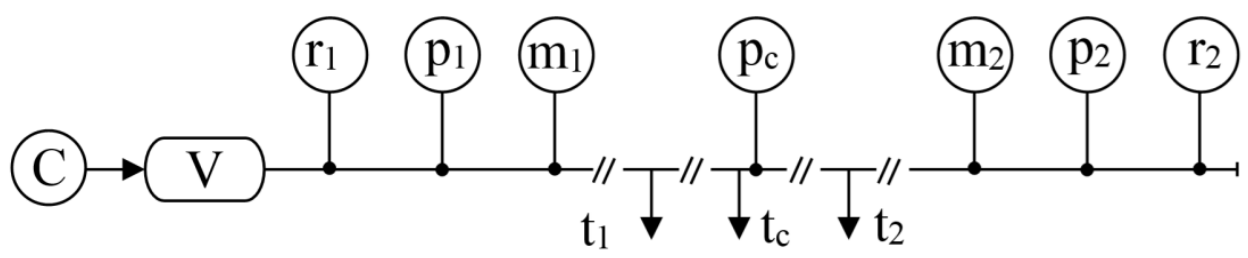

Rys. 1 Schemat stanowiska do badania wycieków z dtugich rurociagów, gdzie: $C$-sprężarka, $V$-zbiornik ciśnieniowy, $r$-korektory, $p$ - czujnik ciśnienia, $m$-czujniki masowego natężenia przepływu, $t$-kraniki.

Zbudowane na podstawie schematu z rys.1. stanowisko zaprezentowano na rys.2.

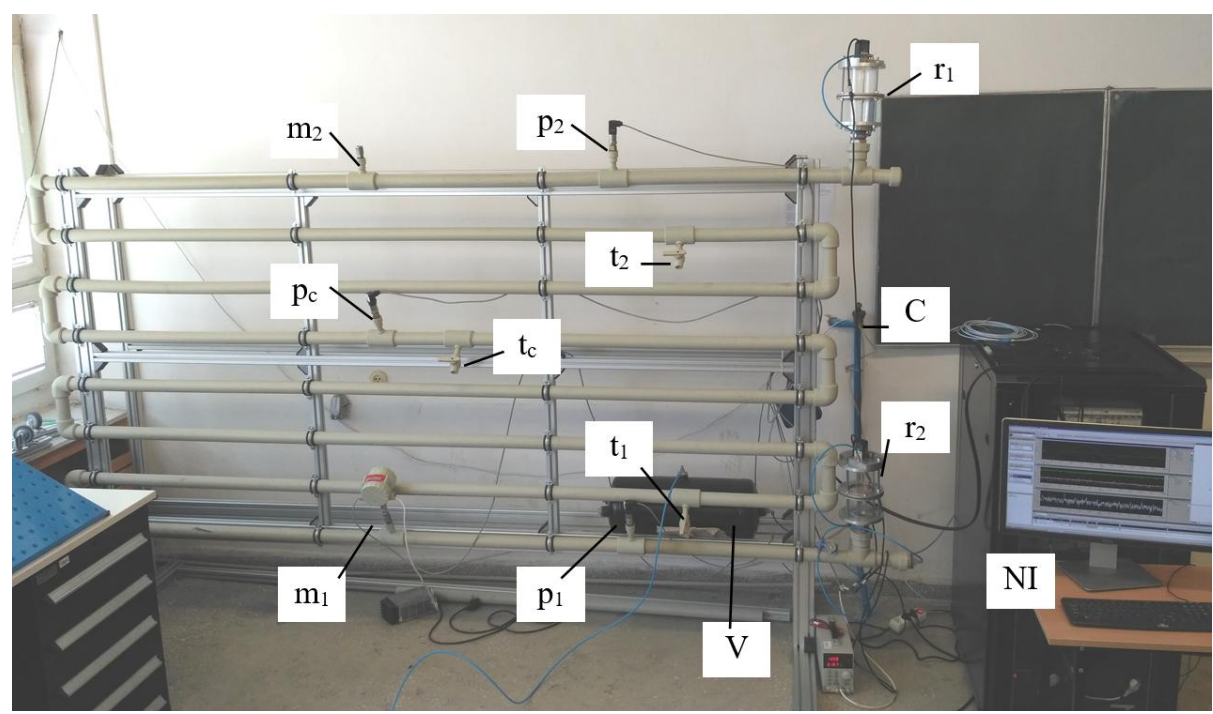

Rys. 2 Stanowisko do badań wycieków z dtugich rurociagów;

gdzie: $C$ - podłaczenie do sprężarki, $V$ - zbiornik ciśnieniowy, $r_{1}, r_{2}$ - korektory, $p_{1}, p_{c}, p_{2}$ - czujniki ciśnienia, $m_{1}$ - czujnik masowego natężenia, $m_{2}$ - miejsce na zamontowanie drugiego czujnika przepływu, $t_{1}, t_{2}, t_{3}-k r a n i k i, N I$ - aparatura pomiarowa.

Stanowisko składa się z 27 metrów zgrzanych rur PPR o średnicy $\phi 45 . \mathrm{Na}$ początku i końcu zamontowano po jednym korektorze. Korektory $\left(\begin{array}{lll}r_{1} & \mathrm{i} & r_{2}\end{array}\right)$ zbudowane zostały $\mathrm{z}$ dwóch komór oddzielonych od siebie wymienną membraną w postaci miedzianej blachy o grubości $0,5 \mathrm{~mm}$. Membrana została tak dobrana aby w chwili zaistnienia wycieku następowało samoistne jej drganie (jest to dodatkowy sygnał diagnostyczny). 
Basics of the corrective - resonant spectral method of gas flow identification... Wyznaczenie podstawy korekcyjno - rezonansowej metody widmowej identyfikacji..

Do pomiaru drań membrany na obudowie korektora wycięty został otwór i wklejone zostało szkło umożliwiające obserwację drgań membrany przez zainstalowany nad nim laserowy czujnik przemieszczeń. Szkło zostało dobrane tak, aby przepuszczało światło o długości fali emitowanej przez czujnik.

Za pierwszym korektorem znajdują się: czujnik do pomiaru ciśnienia $\left(p_{I}\right)$ oraz masowego natężenia przepływu $\left(m_{1}\right)$. Następnie zamontowany został upust do symulacji wycieków gazu $\left(t_{l}\right)$ poprzez upusty powietrza. W bliskości środka rurociągu zainstalowano dodatkowy czujnik ciśnienia $\left(p_{c}\right)$ i upust $\left(t_{c}\right)$. Blisko końca rurociągu znajdują się kolejno: upust $\left(t_{2}\right)$, miejsce do montażu drugiego czujnika masowego natężenia przepływu $\left(m_{2}\right)$ oraz czujnik do pomiaru ciśnienia $\left(p_{2}\right)$.

Powietrze do rurociągu tłoczone jest za pomocą sprężarki, za nią znajduje się zespół przygotowania sprężonego powietrza służący do zadawania odpowiedniego ciśnienia w układzie. Następnym elementem składowym sekcji zasilania jest zbiornik o pojemności 251 pełniąca rolę bufora - aby nie było spadków dopływu powietrza przy symulowanych wyciekach.

Osprzęt pomiarowy podłączony został do aparatury firmy National Instruments (NI), za pomocą której rejestrowane były odczyty z czujników.

\section{Analiza sygnałowa symulowanych wycieków.}

Na rysunkach zaprezentowano przykładowe wyniki badań przy symulacji wycieku $\mathrm{z}$ dolnego upustu - dolnej części rurociągu $\left(t_{l}\right)$. Rys. 3a; przedstawia przebiegi zmian ciśnienia, rys. 3b. zmierzone drgania membrany w korektorze.

a)

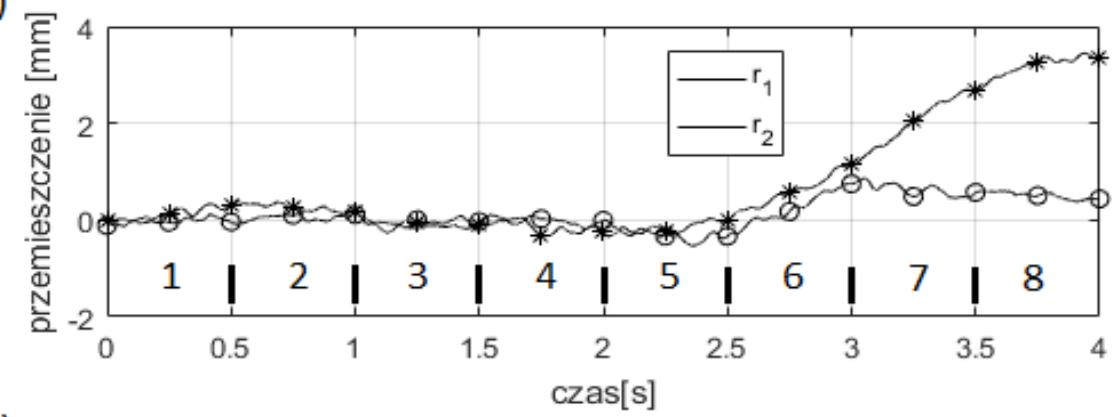

b)

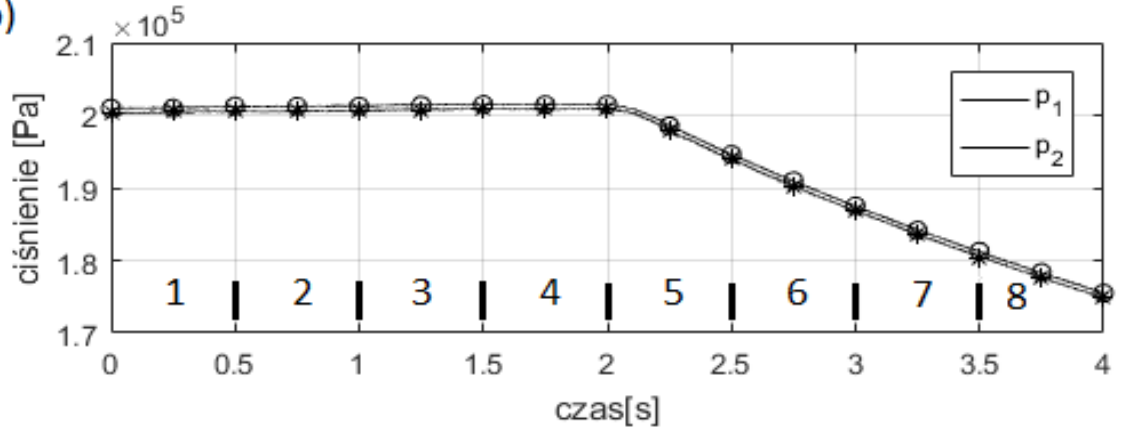

Rys. 3a) Przebieg sygnałów drgań membrany $w$ korektorach $r_{1}$ i $r_{2}$

Rys 3b) Przebieg sygnatów ciśnienia $p_{1} i p_{2}, w$ instalacji podczas wyptywu powietrza z zaworu $t_{1}$ z podziatem na badane odcinki czasu (1-8). 
Z wykresów jednoznacznie można odczytać miejsce symulowanego wycieku, który nastąpił około $2 \mathrm{~s}$ (nastąpił spadek ciśnienia). Na rys.3b. przedstawiono wykres drgania membrany. Punktem odniesienia jest 0 - czyli stan w którym membrana jest nieruchoma - nie drga. Po około 2,5 sekundy można zauważyć rozpoczęcie ruchu, drgań membrany. W obecnej konfiguracji zmiany na wykresach można obserwować jedynie przy większych wyciekach. Przy bardzo małych wyciekach, drgań membrany korektora praktycznie nie da się zaobserwować. W celu zwiększenia czułości zostaną wytłoczone zmniejszające się okręgi na całej powierzchni miedzianej membrany. Testowana była również membrany gumowe o różnej grubości jednak zbyt intensywne drgania powodowały trwałe odkształcanie się powierzchni membrany, stąd decyzja o wymianie. W przyszłości sprawdzona zostanie również opcja $\mathrm{z}$ membraną gumową $\mathrm{z}$ wklejoną na środku miedzianą blaszką. Zabiegi te powinny zdaniem autorów znacznie zwiększyć czułość korektorów.

\section{Podstawy teoretyczne nowej metody diagnozowania wypływu gazu z długich gazociągów}

W zaproponowanej metodzie identyfikacji wypływu gazu mogą zostać wykorzystane sygnały: $y$ - sygnał $\mathrm{z}$ wybranego czujnika (ciśnienia lub masowego natężenia przepływu), $x$ - sygnał otoczenia oraz nowy sygnał $\mathrm{z}$ korektora $r$ (przemieszczenie membrany). Na podstawie trzech sygnałów można wyznaczyć wiele wariantów sygnałów określonych $\mathrm{w}$ domenie częstotliwości $\omega$ : gęstości widmowe mocy sygnałów własne $S_{x x}, S_{y y}, S_{r r}$ i wzajemne $S_{x y}, S_{x r}, S_{y r}$ [10].

Wykorzystanie do analizy mocy sygnałów pozwala na przejście od diagnostyki sygnałowej do diagnostyki parametrycznej, która jest skuteczniejsza. W nowej metodzie wykorzystuje się możliwości przejścia od sygnałów w przestrzeni czasu $t$ i przestrzeni czasu $\tau$ do sygnałów w domenie częstotliwości $\omega$ wynikające $\mathrm{z}$ teorii przetwarzania sygnałów $[3,6,14]$.

Zatem relacje miedzy sygnałami $S_{y r}$ są wyrażone w postaci wzmocnienia amplitudowego $\left(A^{2}\right)$ i przesunięcia fazowego $\phi$.

$$
\begin{gathered}
A^{2}=\frac{S_{y y}}{S_{x x}} \\
\varphi=\operatorname{Arg} \frac{S_{y x}}{S_{x x}}
\end{gathered}
$$

gdzie: $y$ - sygnał z wybranego czujnika, $x$ - sygnał otoczenia

Można założyć, że otoczenie nie zmienia się jeżeli okres obserwacji następujących po sobie odcinkach czasu tego samego sygnału lub różnych sygnałów analizowanych w tym samym czasie będzie bardzo krótki. 
Basics of the corrective - resonant spectral method of gas flow identification... Wyznaczenie podstawy korekcyjno - rezonansowej metody widmowej identyfikacji..

Wtedy można wyznaczyć nową abstrakcyjną fizycznie interpretowalną wielkość w postaci ilorazu wzmocnienia amplitudowego:

$$
A_{y y}^{2}=\frac{\frac{S_{y y}^{T 12}}{S_{x x}^{T 12}}}{\frac{S_{y y}^{T 01}}{S / x x}} \underset{S_{x x}^{T 11} \cong S_{x x}^{T 01}}{\longrightarrow} \frac{S_{y y}^{T 12}}{S_{y y}^{T 01}} \text { (5) lub } A_{r y}^{2}=\frac{\frac{S_{r r}}{S / x x}}{\frac{S_{y y}}{S / x x}} \stackrel{S_{x x} \cong S_{x x}}{\longrightarrow} \frac{S_{r r}}{S_{y y}} \text { (6) }
$$

gdzie: $T^{01}, T^{12}$ - następujące po sobie krótkie okresy czasu.

Dany model można również zapisać w postaci sparametryzowanej:

$$
A^{2}=\frac{M_{0}+M_{1} s+M_{2} s^{2}+\ldots+M_{n} s^{n}}{L_{0}+L_{1} s+L_{2} s^{2}+\ldots+L_{n} s^{n}}
$$

W zaproponowanej metodzie identyfikacji wypływu gazu zostanie wykorzystany sygnał $\mathrm{z}$ korektora $r_{l}$ (przemieszczenie membrany) oraz sygnał $\mathrm{p} 1 \mathrm{z}$ czujnika ciśnienia. Na podstawie dwóch sygnałów zostaną wyznaczone parametry modelu $\mathrm{A}^{2} \mathrm{w}$ dwóch wariantach. W pierwszym przypadku sygnał $r_{l}$ (4 sekundowy) został podzielony na 8 mniejszych części trwających po $0,5 \mathrm{~s}$ (rys. 3a.). Co pozwoliło na wykonanie założenia, że w krótkich odcinkach czasu otoczenie nie zmieni się.

Obliczenia zostały przeprowadzone poprzez użycie w modelu pierwszym (wzór 8) sygnału $r_{l}$ z kolejno następujących po sobie odcinków czasowych. W drugim przypadku w tych samych odcinkach czasu użyte były gęstości widmowe mocy dwóch różnych sygnałów $r_{l}$ i $p_{l} \mathrm{w}$ tym samym odcinku czasu.

Modele diagnostyczne $A^{2}$ będą przyjmują następującą postać:

$$
\begin{aligned}
& A_{r 2 r 1}^{2}=\frac{S_{r 1 \_2}}{S_{r 1 \_1}} \\
& A_{r 1 p 1}^{2}=\frac{S_{r 1 \_1}}{S_{p 1 \_1}}
\end{aligned}
$$

gdzie: $r_{l_{-} 2}-$ drgania membrany w korektorze $r_{l} \mathrm{w} 2$ badanym odcinku czasu (od 0,5 do $1 \mathrm{~s}-$ wg. rys. 3a.), itp.

W tab. 1. Przedstawione zostały parametry dla modelu $\mathrm{A}_{\mathrm{r} 1 \mathrm{r} 1}^{2}$, a dla $\mathrm{A}_{\mathrm{rlp} 1}^{2} \mathrm{~W}$ tab. 2. 
Tab. 1 Wspótczynniki modelu $A^{2}{ }_{r I r l}$ (rys. $\left.3 b\right)$ dla sygnatu $z$ pierwszego korektora $\left(r_{1}\right)$ w różnych odcinkach czasu

\begin{tabular}{|c|c|c|c|c|c|c|c|c|c|c|c|c|}
\hline & $\mathbf{L}_{0}$ & $\mathbf{L}_{1}$ & $\mathbf{L}_{2}$ & $\mathbf{L}_{3}$ & $\mathbf{L}_{4}$ & $\mathbf{L}_{5}$ & $\mathbf{M}_{0}$ & $\mathbf{M}_{1}$ & $\mathbf{M}_{2}$ & $\mathbf{M}_{3}$ & $\mathbf{M}_{4}$ & $\mathbf{M}_{5}$ \\
\hline$A_{r 2 r 1}^{2}$ & 0,84 & $-1,13$ & 0,07 & 0,50 & 030 & 0,17 & 0,94 & $-1,13$ & 0,05 & 0,50 & $-0,38$ & 0,17 \\
\hline $\mathbf{A}_{\mathrm{r} 3 \mathrm{r} 2}^{2}$ & 1,19 & $-1,15$ & $-0,02$ & 0,51 & $-0,37$ & 0,16 & 0,84 & $-1,13$ & 0,07 & 0,50 & $-0,39$ & 0,17 \\
\hline $\mathbf{A}_{\mathrm{r} 4 \mathrm{r} 3}^{2}$ & $-0,03$ & $-0,95$ & 0,24 & 0,44 & $-0,41$ & 0,19 & 1,19 & $-1,15$ & $-0,02$ & 0,51 & $-0,37$ & 0,16 \\
\hline $\mathbf{A}_{\mathrm{r} 5 \mathrm{r} 4}^{2}$ & 0,38 & $-1,05$ & 0,18 & 0,46 & $-0,41$ & 0,19 & $-0,03$ & $-0,95$ & 0,24 & 0,44 & $-0,41$ & 0,19 \\
\hline$A_{r 6 r 5}^{2}$ & 1,03 & $-1,15$ & 0,03 & 0,51 & $-0,38$ & 0,16 & 0,38 & $-1,05$ & 0,18 & 0,46 & $-0,41$ & 0,19 \\
\hline$A_{r 7 r 6}^{2}$ & 1,01 & $-1,15$ & & 0,51 & $-0,38$ & & & & 0,03 & 0,51 & $-0,38$ & 0,16 \\
\hline $\mathbf{A}_{\mathrm{r} 8 \mathrm{r} 7}^{2}$ & 0,97 & $-1,15$ & 0,05 & 0,50 & $-0,38$ & 0,17 & 1,01 & $-1,15$ & 0,04 & 0,51 & $-0,38$ & 0,16 \\
\hline
\end{tabular}

Tab. 2 Wspótczynniki modelu $A_{r l p 1}^{2}$ (rys. $3 a$. i rys.3b..) - dla sygnału z pierwszego korektora $\left(r_{l}\right)$ i z pierwszego czujnika ciśnienia $\left(p_{1}\right)$ w różnych odcinkach czasu

\begin{tabular}{|c|c|c|c|c|c|c|c|c|c|c|c|c|}
\hline & $\mathbf{L}_{0}$ & $\mathbf{L}_{1}$ & $\mathbf{L}_{2}$ & $\mathbf{L}_{3}$ & $\mathbf{L}_{4}$ & $\mathbf{L}_{5}$ & $\mathbf{M}_{0}$ & $\mathbf{M}_{1}$ & $\mathbf{M}_{2}$ & $\mathbf{M}_{3}$ & $\mathbf{M}_{4}$ & $\mathbf{M}_{5}$ \\
\hline $\mathbf{A}_{\mathrm{r} 1 \mathrm{p} 1}^{2}$ & 0,94 & $-1,13$ & 0,05 & 0,50 & $-0,38$ & 0,17 & 0,85 & $-1,14$ & 0,08 & 0,50 & $-0,39$ & 0,17 \\
\hline $\mathbf{A}_{r 2 p 2}^{2}$ & 0,84 & $-1,13$ & 0,07 & 0,50 & $-0,39$ & 0,17 & 0,85 & $-1,14$ & 0,08 & 0,50 & $-0,39$ & 0,17 \\
\hline $\mathbf{A}_{\mathrm{r} 3 \mathrm{p} 3}^{2}$ & 1,19 & $-1,15$ & $-0,02$ & 0,51 & $-0,37$ & 0,16 & 0,85 & $-1,14$ & 0,08 & 0,50 & $-0,39$ & 0,17 \\
\hline $\mathbf{A}_{\mathrm{r} 4 \mathrm{p} 4}^{2}$ & $-0,03$ & $-0,95$ & 0,24 & 0,44 & $-0,41$ & 0,19 & 0,85 & $-1,14$ & 0,08 & 0,50 & $-0,39$ & 0,17 \\
\hline $\mathbf{A}_{r 5 p 5}^{2}$ & 0,38 & $-1,05$ & 0,18 & 0,46 & $-0,41$ & 0,19 & 0,85 & $-1,14$ & 0,08 & 0,50 & $-0,39$ & 0,17 \\
\hline$A_{r 6 p 6}^{2}$ & 1,03 & $-1,15$ & 0,03 & 0,51 & $-0,38$ & 0,16 & 0,85 & $-1,14$ & 0,08 & 0,50 & $-0,39$ & 0,17 \\
\hline $\mathbf{A}_{\mathrm{r} 7 \mathrm{p} 7}^{2}$ & 1,01 & $-1,15$ & 0,04 & 0,51 & $-0,38$ & 0,16 & 0,85 & $-1,14$ & 0,08 & 0,50 & $-0,39$ & 0,17 \\
\hline $\mathbf{A}_{\mathrm{r} 8 \mathrm{p} 8}^{2}$ & 0,97 & $-1,15$ & 0,05 & 0,50 & $-0,38$ & 0,17 & 0,85 & $-1,14$ & 0,08 & 0,50 & $-0,39$ & 0,17 \\
\hline
\end{tabular}

Z rysunku 3 widać że wyciek nastąpił po około 2 sekundach. Na podstawie analizy tab. 1 również dany wyciek widać $\mathrm{w}$ zmianie parametrów modelu $\mathrm{A}_{\mathrm{r} 4 \mathrm{r} 3}^{2}(2 \mathrm{~s} \div 1,5)$ i $\mathrm{A}^{2}{ }_{\mathrm{r} 5 \mathrm{r} 4}(2,5 \mathrm{~s} \div 2 \mathrm{~s}) \mathrm{w}$ porównaniu do parametrów modeli $\mathrm{w}$ innych czasach. Znaczącą zmianę parametrów można zaobserwować na parametrach $\mathrm{L}_{0} \mathrm{i} \mathrm{M}_{0}$. W przypadku tabeli 2 również nastąpiła zmiana parametrów w momencie symulowanego wycieku $\mathrm{A}_{\mathrm{r} 4 \mathrm{p} 4}^{2}$ (około 2 sekundy), $\mathrm{A}_{\mathrm{r} 5 \mathrm{p} 5}^{2}$ (około 2,5 sekundy). Znacząca zmiana parametrów na parametrze $\mathrm{L}_{0}$.

W kolejnych artykułach przeanalizowane zostanie w jakim przypadku następować będą również zmiany pozostałych parametrów oraz zbadane będą modele w postaci różnicy przesunięć fazowych.

Wyniki badań zostaną również zweryfikowane po modyfikacji obecnego stanowiska wg uwag opisanych w rozdziale 3. 
Basics of the corrective - resonant spectral method of gas flow identification... Wyznaczenie podstawy korekcyjno - rezonansowej metody widmowej identyfikacji..

\section{Podsumowanie}

W artykule przedstawiono stanowisko laboratoryjne do badania wypływu gazu $\mathrm{z}$ długich gazociągów. Zaprezentowano wyniki pomiarów przy symulowanych znacznych wypływach. Opisano etapy kolejnych modyfikacji mających na celu zwiększenie czułości zamontowanych korektorów, a zatem zwiększenie zmiany przebiegu sygnału $\mathrm{w}$ przypadku nawet małych wycieków. Została również przedstawiona koncepcja nowej metody diagnostycznej opierającej się na sygnałach gęstości widmowej mocy własnej i wzajemnej, które również bazując na sygnałach generowanych przez dołączone korektory.

Należy również zaznaczyć że użyte korektory w najmniejszym stopniu nie wpływają na jakość statyczną i dynamiczną badanych gazociągów.

Dodatkowo przejście na czasowo - częstotliwościową analizę sygnałów (poprzez zastosowanie sparametryzowanego modelu $A^{2}$ i $\varphi$ ) da dużo większą możliwość niż stosowanie metod bazujących na wskaźnikach jakości, których liczba jest ograniczona.

\section{Literatura}

[1] Abdulimen K. E., Susu A. A., Liquid pipeline leak detection system: model development and numerical simulation, Chemical Engineering Journal, Volume 97, Issue 1, 2004.

[2] Grądzki R, Golak K, Lindstedt P, Bartoszewicz B. Reasons for the experimental research of gas outflows based on the signals of weak interactions between the tested model of the gas pipeline, and tested equalizer. Journal of KONBiN 2015, nr 2(34) s.39-48.

[3] Grądzki R, Golak K, Lindstedt P. Parametric and nonparametric diagnostic models for blades in the rotating machinery with environment elimination. Journal of KONES Vol. 23, nr 2 (2016), s. 137-145

[4] Kowalczuk Z., Gunawickrama K.: Detekcja i lokalizacja wycieków w rurociągach przesyłowych. Rozdział 21 pracy zbiorowej pod red. J. Korbicza, J. Kościelnego, Z. Kowalczuka i W. Cholewy: Diagnostyka procesów. Modele metody sztucznej inteligencji, zastosowania. Warszawa, WNT, 2002.

[5] Kunze U., Experience with the acoustic leakage monitoring system, Prog Nucl Energy, 34 (3) (1999).

[6] Lindstedt P., Grądzki R., Model for blade diagnosis in a working rotor machine employing the method of virtual elimination of stochastic environment. Archive of Mechanical Engineering, Vol. 58, nr 3 (2011), s. 305-318.

[7] Lindstedt P., Słabe interakcje w procesie diagnozowania wycieków z układów hydraulicznych, Prace naukowe ITWL. Zeszyt nr 102000.

[8] Lindstedt P., The method of complex worthiness assessment of an engineering object in the process of its use and service, Solid State Phenomena, vol. 144/2009, Trans Tech Publications, Switzerland 2009.

[9] Lindstedt P., Weak interactions between objects in the signal-based and parametric diagnostics of transport-dedicated complex engineering systems, Aircraft Engineering and Aerospace Technology Vol.77, nr 3 (2005), s. 222-227.

[10] Lindstedt P.,Praktyczna diagnostyka maszyn i jej teoretyczne podstawy, Wydawnictwo Naukowe ASKON, Warszawa 2002. 
[11] Liu, A. E., February 2008. Overview: Pipeline Accounting and Leak Detection by Mass Balance, Theory and Hardware Implementation.

[12] Scott, S. L., and Barrufet, M. A., 2003, "Worldwide Assessment of Industry Leak Detection Capabilities for Single \& Multiphase Pipelines," Project Report Prepared for the Minerals Management Service, OTRC Library Number: 8/03A120, University of Texas, Austin.

[13] Sivathanu Y. Natural Gas Leak Detection in Pipelines. U.S. Department of Energy, National Energy Technology Laboratory, 2003

[14] Szabatin J., Podstawy teorii sygnałów, WKŁ Warszawa 2000.

[15] Tomasik P. Zastosowania modeli dokładnych sieci do detekcji i lokalizacji wycieków. In: Diagnostics of Processes and Systems; 2011. p. 507-512.

[16] Zhang J.: Statistical pipeline leak detection forall operating conditions. Pipeline \& Gas Journal, February 2001.

\section{Rafat Grązki część powyższych badań zrealizowal w ramach pracy S/WM/1/2016 i sfinansowal ze środków na naukę MNiSW.}

\section{Karol Golak część powyższych badań zrealizowat w ramach pracy S/WM/2/2017 i sfinansowal ze środków na naukę MNiSW.}

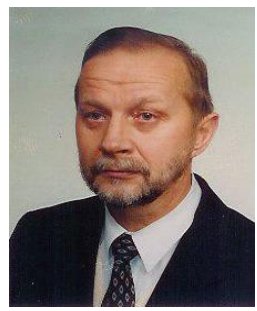

Prof. dr hab. inż Pawet Lindstedt, profesor zwyczajny Instytutu Technicznego Wojsk Lotniczych. Tematyka badawcza: budowa $i$ eksploatacja maszyn, automatyka stosowana, diagnostyka $i$ niezawodnośc urzadzeń technicznych. Jego prace skupiaja sie głównie na zagadnieniach związanych $z$ diagnostyka silników lotniczych, systemów hydraulicznych, diagnostyce wibroakustycznej i procesach zuzycia. (Udziat 33\%)

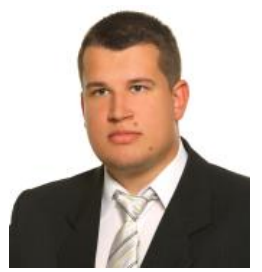

Dr inz. Rafal Gradzki, adiunkt Wydziatu Mechanicznego Politechniki Białostockiej. Tematyka badawcza: diagnostyka techniczna maszyn wirnikowych $i$ silników autobusowych, badania potencjału niezawodności i bezpieczeństwa, diagnostyka wibroakustyczna. (Udziat 33\%)

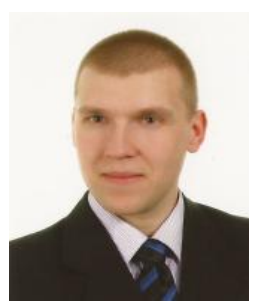

Dr inj. Karol Golak, adiunkt Wydziatu Mechanicznego Politechniki Białostockiej. Tematyka badawcza: diagnostyka techniczna silników odrzutowych, niezawodność $i$ regulacja urządzeń mechanicznych. (Udziat 33\%) 